\title{
Terapi Realitas Dan Konsep Sabar Dalam Physical Distancing Mahasiswi Di Asrama Astri Aulia
}

\author{
Ratna Wulan \\ Universitas Islam Negeri Sunan Kalijaga Yogyakarta \\ ratnawulanssosma@gmail.com
}

\begin{abstract}
Abstrak
Covid-19 merupakan salah satu penyakit yang sangat mudah menular sehingga dapat mengguncangkan psikologis individu. Salah satu cara untuk memutuskan rantai penyebarannya yaitu dengan pola hidup bersih, mencuci tangan, menggunakan masker serta membangun physical distancing untuk tetap di rumah serta melakukan semua aktivitas di dalam rumah. Physical distancing ini tentu saja akan menimbulkan faktor kegelisahan, karena mempersempit aktivitas individu di luar rumah sehingga sinilah butuh kesabaran dalam menerima kebutuhan seperti ini. Penelitian berfokus pada terapi realitas dan konsep sabar dalam melaksanakan physical distancing terhadap mahasiswi di asrama Astri Aulia Yogyakarta. Penelitian ini adalah penelitian lapangan dengan menggunakan metode deskriptif kualitatif. Teknik pengumpulan data dilakukan dengan observasi, wawancara dan dokumentasi. Hasil penelitian adalah terapi realitas dan konsep sabar mampu memberikan dampak perubahan pada diri klien dan dilihat dari sisi agama, terapi realitas mampu mengawetkan rasa sabar dalam kehidupan individu untuk membangun physical distancing.
\end{abstract}

Kata kunci: Physical distancing, Sabar, Terapi Realitas

\begin{abstract}
Reality Therapy And Patience Concept In Physical Distancing Students At Astri Aulia Hostel. Covid-19 is a highly contagious disease that can shake an individual's psychological well-being. One way to break the chain of distribution is to live a clean lifestyle, wash hands,
\end{abstract}


use masks and build physical distancing to stay at home and do all the activities in the house. Physical distancing, of course, will cause anxiety factors, because it narrows individual activities in the house, so this is where patience is needed to accept such needs. The research focuses on reality therapy and the concept of patience in carrying out physical distancing of female students at the Astri Aulia Yogyakarta dormitory. This research is a field research using qualitative descriptive methods. Data collection techniques are done by observation, interview and documentation. The results of the study are reality therapy and the concept of patience is able to have an impact on the client and in terms of religion, reality therapy is able to preserve patience in the lives of individuals to build physical distancing.

Keywords: Physical Distancing; Patience; Reality Therapy

\section{A. Pendahuluan}

Pada akhir tahun 2019 tepatnya pada tanggal 31 Desember, dunia kedatangan tamu tidak diundang yang dapat mengguncangkan psikologis jiwa secara massal. Tamu atau virus yang sangat dikenal tersebut bernama corona atau dalam bahasa Inggirs disebut coronavirus. Kasus virus ini pertama kalinya dilaporkan lahir di kota Wuhan, provinsi Hubei, tepat, seiring berjalannya waktu kini telah tersebar dan merambat lebih ke berbagai negara bagaikan benalu di hutan belantara. Dunia seakan lumpuh, ekonomi hancur, hampir semua negara di dunia tidak ada yang selamat dari efek virus tersebut. Krisis kesehatan pun terjadi, di karenakan wabah corona menular dengan sangat cepat yang dibuktikan telah menyebar ke seluruh dunia sehingga WHO mengambil langkah untuk menetapkan virus ini sebagai pandemic agar setiap negara waspada dan tidak merehkan kasus yang sedang booming dan viral sekarang ini. Di karenakan virus corona menjadi permasalahan dunia WHO (World health organization) kemudian memberikan nama resmi terhadap virus dengan sebutan covid-19. Covid-19 adalah sebuah akronim, kependekan dari Co dinisabatkan untuk corona dan Vi untuk virus sedangkan D untuk Disease yang berarti penyakit. Kemudian angka 19 tersebut merujuk pada kemunculan wabah tersebut yakni pada akhir tahun 2019 (corona virus disease) (Anon 2020). Covid-19 merupakan bagian dari virus tipe corona (SARS-CoV) yang 
mampu menyerang saluran pernafasan manusia, sehingga menyebabkan gangguan fungsi pada saluran pernapasan (Li et al. 2020). Sehingga berdampak pada banyaknya korban jiwa akibat covid-19. Covid-19 menggerogoti dan menghampiri siapa saja tanpa memandang usia mulai dari balita, anak-anak, remaja, dewasa bahkan lansia, pria, wanita, orang kaya dan miskin bahkan tidak berpihak pada status sosial, ekonomi serta jabatan. Selanjutnya, hal ini mempersempit aktifitas setiap individu di luar rumah serta mengharuskan untuk menaati kebijakan pemerintah dan protokol tenaga medis agar tetap di rumah serta melakukan setiap kegiatan dari rumah seperi halnya keberlangsungan pendidikan serta pekerjaan.

Guna mengurangi efek yang ditimbulkan dari pandemi tersebut meluas, maka hamper seluruh dunia menghimbau serta memberikan arahan kepada seluruh masyarakat agar melakukan social distancing (Ibadurrahman 2020). World health organization menghimbau kepada dunia agar tidak panik terhadap pandemik yang sedang dihadapi bersama, serta melakukan social distancing agar mata rantai penyebaran virus dapat terputus dengan cara meningkatkan pola hidup bersih seperti menggunakan disinfektan setelah menjamah sesuatu, mencuci tangan dengan menggunakan air bersih dan sabun atau hand sanitizer, menggunakan masker ketika sakit, dan juga untuk tidak menyentuh mata, hidung dan mulut.

Di Indonesia, presiden RI menghimbau kepada masyarakat melakukan social distancing dengan menerapkan beberapa aturan terkait yang tertuang dalam Peraturan Pemerintah Nomor 21 Tahun 2020 Tentang Pembatasan Sosial Berskala Besar dalam Rangka Percepatan Penanganan Corona Virus Disease 2019 (Covid-19) (Presiden RI 2020). Salah satunya dengan cara tetap di rumah saja agar corona virus tidak menyebar dengan cepat. Berdasarkan keterangan para dokter covid-19 menyebar terjadi sangat cepat melalui udara, dengan penularan melalui dropless yang dikeluarkan dari mulut atau hidung saat bersin ataupun interaksi-interasi lainnya yang mampu memicu penularan. Dalam buku yang di tulis oleh Samsul Hadi menyebutkan bahwa gejala klinis yang dialami oleh individu covid-19 diantaranya ditandai dengan demam, batuk, gangguan pernafasan akut, timbul gambaran pneumonia, terkadang juga terdapat gejala 
saluran pencernaan dan penciuman seperti diare ataupun kehilangan perasa dan pembau (Hadi 2019). Bagi orang-orang yang terinfeksi virus tersebut disarankan melakukan karantina/ isolasi baik secara mendiri ataupun oleh pihak terkait yang berlangsung hingga akhir masa inkubasi virus. Setelah karantina, jika gejala akibat virus belum muncul, maka pihak terkait dapat kembali kepekerjaannya. Masa inkubasi untuk penyakit virus dapat berlangsung beberapa hari atau minggu. Lamanya masa inkubasi dikenal dengan sebagian besar infeksi. sedangkan untuk covid-19 periode inkubasi maksimum diperkirakan 14 hari, namun ada yang mengatakan mungkin lebih lama (Bruno 2020).

Perlu adanya kerjasama semua pihak dalam memutus mata rantai covid-19. Baik dari pemerintah, tenaga medis maupun masyarakat luas. Berbagai kebijakan dikeluarkan oleh pemerintah terkait dengan mitigasi dalam menangani virus tersebut. Hal tersebut salah satu nya yang dilakukan oleh Majelis Ulama Indonesia, dengan mengeluarkan fatwa terkait tata melakukan pelaksanaan ibadah di masjid atau tempat ibadah selama berlangsungnya pandemi (Majelis Ulama Indonesia 2020). Selain itu juga, para influencer mencakup youtuber misalnya, vloger, komikus, instagramer juga memberikan berbagai edukasi pemahaman kepada masyarakat terkait pola perilaku selama masa pandemi.

Bentuk-bentuk dari mitigasi berupa pencegahan dan penanggulangan penyebaran rantai virus corona yang dilakukan dalam kehidupan salah satunya dengan penerapan menjaga jarak social (Presiden RI 2020). Menjaga jarak dimaksudkan WHO (dalam Kresna and Ahyar 2020) dari pada physical distancing, ini memberikan pemahaman bahwa psikokologis dari menjaga jarak itu sendiri dalam artian manusia masih bisa melakukan interaksi dalam jarak tertentu (satu atau dua meter dari lawan interaksinya). Psikologisnya tidak secara total untuk tidak berinteraksi dengan individu lainnya. Dengan adanya physical distancing di memberikan harapan kepada diri sendiri agar tidak tertular covid-19.

Upaya mitigasi hendaknya dilakukan oleh semua lapisan masyarakat. pertama yang dilakukan diantaranya upaya preventif agar tidak terjadi kemungkinan terinfeksi 
corona virus yaitu untuk tetap di rumah (stay at home). Stay at home di lakukan bertujuan untuk menjalani social distancing. Pemerintah telah menghimbau dan menetapkan peraturan agar masyarakat melakukan sosial distancing, sesuai dengan undang-undang nomor 6 tahun 2018 tentang Kekarantinaan Kesehatan (Presiden RI 2018). Disisi lain karena situasi semakin berbahaya maka tidak hanya social distancing penerintahan maupun WHO juga menekankan untuk melakukan physical distancing. Penerapan physical distancing bertujuan agar tidak terjadi kontak tubuh atau tidak diperkenannya untuk berjabat tangan dengan orang lain terutama dengan orang sakit yang berisiko tinggi menderita covid-19, menunda kegiatan di luar rumah (Los Angeles Country Departemen Of Public Health 2020). Sosial distancing yang dianjur oleh pemerintah dengan menerapkan physical distancing. Semua kegiatan dilakukan di rumah, seperti bekerja dari rumah (work from home), belajar dirumah, semua bisa dilakukan di rumah.

Awalnya pandangan masyarakat secara umum wabah corona virus dianggap sebagai musuh yang mengundang sejuta masalah, banyak tulisan dan ceramah yang menegaskan bahwa virus tersebut dianggap sebagai siksaan dari Tuhan (Supriatna 2020). Banyak kalangan menerima idiologi semacam ini apalagi dilihat dengan kepercayan, makanan, gaya hidup bahkan politik penduduk dan pemerintahan Cina masanya. Setelah corona virus menjamur dan menyebar kenegara-negara lain termasuk Indonesia terkhusus menyerang kaum muslim yang taat maka pandangan yang mulanya dianggap sebagai siksaan Allah mulai sirna walaupun kemungkinan masih ada yang menganutnya. Ditilik dari perspektif islam, virus atau musuh yang tidak terlihat dengan kasat mata ini memberikan hikmah yang sangat luar biasa terhadap orang-orang yang berfikir terutama orang islam (Indriya 2020). Dengan adanya peristiwa pandemic ini, tidak hanya efek buruk yang terjadi dalam masyarakat, melainkan juga berbagai hikmah di balik peristiwa tersebut (Tasri 2020). Diantaranya banyak imam-imam baru bermunculan di rumah-rumah, salat sunnah menjadi rutinitas, juru masak pun hadir di dapur-dapur, orang tua yang dinyatakan sebagai madrasatul ula kini menjalankan perannya di rumah secara efektif. Menyadarkan orang-orang kaya yang tidak pernah 
mengeluarkan zakat untuk berinfak, saling tolong menolong dan bahu membahu agar tetap bisa hidup. Di negara lain, Jerman misalnya dilansir Republika.co.id Negara pertama kalinya dalam 12 tahun azan diperbolehkan untuk dikumandangkan dengan pengeras suara atau secara terbuka walaupun orang muslim tidak bisa pergi ke masjid dan tidak bisa melaksanakan salat bersama. Hal ini terjadi atas permintaan ketua asosiasi Negara DITIB NRW (Aossoiasi Muslim Jerman di Dusiburg) Hulya Ceylan dan juga karena adanya tawaran dari gereja-gereja tetangga untuk menyerukan azan (Sya'ban 2017). Penduduk Jerman menganggap azan sebagai panggilan untuk berdoa dan tanda solidaritas antar agama di saat krisis, serta sebagai bentuk penyampaian moralitas, kekuatan juga kenyamanan kepada komunitas muslim sehingga muslim di Eropa juga ikut terlibat memerangi penyebaran virus.

Covid juga mengajarkan para perempuan untuk menutup aurat bahkan diantaranya memilih untuk menggunakan niqab dibandingkan masker, bahkan para desainer busana kini mengeluarkan model jilbab dan masker dalam satu bentuk sehingga terlihat seperti berniqob (Tasri 2020). Di lansir fin.co.id negara Eropa, Prancis yang pada awalnya mengeluarkan peraturan pada April 2011 melarang memakai kerudung di tempat umum sebagai perbuatan ilegal, terlebih cadar dan niqab dengan alasan agar bisa dikenali. Kini dampak covid-19 para desainer merancang busana yang dengan penutup wajah dan kerudung, bahkan di acara The Fasion Week, para model memperkenalkan berbagai macam jenis masker wajah yang identik dengan yang dipakai wanita muslim di seluruh dunia

Menurut Quraish Shihab dalam bukunya peristiwa semacam ini tidak dapat dikatakan sebagai siksa dari Ilahi karena corona virus ini menimpa orang muslim dan nonmuslim baik yang durhaka maupun taat. Dari alquran juga diperoleh kesan yang sangat kuat bahwa ketika Allah hendak menjatuhkan siksa atas satu kaum, maka terlebih dahulu diselamatkan hamba-hamba-Nya yang taat agar tidak ikut tertimpa siksaan (Shihab 2020). Hal ini terlukis dalam narasi kisah Nabu Nuh a.s. dan Nabi Luth a.s. dalam alquran surah Hud ayat 26-17. Maka bencana merupakan siksa, dan jika bencana menimpa seluruh umat manusia tanpa memandang kepercayaan, agama, iman, 
individu yang zalim/ durhaka ataupun individu yang ketaatan, maka ia dinamai fitnah atau bala. Kedua kata tersebut digunakan dalam alquran sebagai ujian atau cobaan dari Allah (Shihab 2020).

Firman Allah

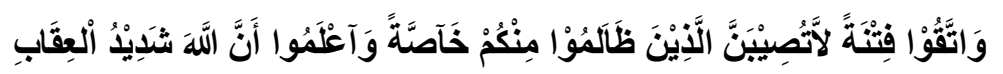

"Dan peliharalah/hati-hatilah dirimu dari pada siksaan/ujian yang tidak hanya menimpa orang-orang yang zalim di antara kau dan ketahuilah bahwa Allah sangat keras siksaan-Nya" (Q.S. al-Anfal [8]: 25)

Dan Allah juga menegaskannya dalam QS. an-Nisa (4): 147 yang artinya "Untuk apa Allah menyiksa kamu kalau kamu bersyukur dan beriman? Allah Maha Bersyukur Lagi Maha Mengetahui" dari kedua ayat dapat ditarik kesimpulan bahwa yang dimaksudkan dengan siksaan duniawi tujuannya agar manusia bertaubat, melakukan kebaikan dan menjauhi keburukan. Sehingga Allah tidak akan menjatuhkan siksaan jika hal tersebut telah diterpretasikan dalam kehidupan. Sehingga jelaslah bahwa siksa dan azab berbeda konteksnya (Shihab 2020).

Di masa krisis kesehatan seperti ini, sikap sabar untuk melakukan social distancing untuk tetap di rumah penting ditanam di dalam diri masing-masing individu . karena dibalik tabir kesabaran aka nada hikmah dan pelajaran (Sukino 2018). Dan kenhancuran atau dampak yang akan didapat ketika seorang individu tidak memiliki sifat sabar dan terlalu tergesa-gesa terhadap apa yang ingin dilakukan. Maka segala yang dilakukannya bersifat tidak langgeng terhadap kenikmatan yang diperbuat. Keadaan untuk menjaga jarak dan tetap dirumah kemungkinan dengan berjalannya waktu akan menjadikan seoarang individu merasa bosan dan stress atau dalam istilah psikolog disebut dengan cabin fever (Admin 2020). Sehingga sabar dalam islam mampu mengendalikan individu untuk melaksanakan himbauan pemerintah. Salah satu faktor penting dalam spirituallitas islam adalah kesabaran (Hadi 2018), karena kesabaran merupakan salah satu cara yang diajarkan islam ketika seorang individu menghadapi masa sulit. Dan Alquran memerintahkan kepada manusia untuk menjadikan sabar 
sebagai media untuk mendapatkan pertolongan Allah dalam menghadapi berbagai masalah atau kesulitan hidup (Uyun and Rumiani 2012).

Penelitian yang dilakukan oleh, Nurul Iman studi komparasi sabar konsep Hasbi dan Nasution tentang sabar, di simpulkan bahwa konsep sabar sangat relevan dengan kesehatan mental. Sabar merupakan indicator kesehatan mental karena dalam sabar tersirat kemapuan individu memikul kesulitan hidup, tegar dalam menghadapi berbagai bencana dan cobaan hidup. Tidak emnjadikan individu lemah, terpuruk, dan tidak meliputi keputusasaan. Orang yang mampu menghadapi berbagai cobaan dan situasi sulit dengan kesabaran adalah orang yang memiliki kepribadian yang paripurna. Konsep sabar Hasbi dan Nasution dapat dijadikan materi bagi seorang konselor dalam membimbing klien yang belum atau sedang menghadapi maslah (Imam 2012).

Antara sabar dan syukur ada keterkaitan seperti keterkaitan antara nikmat dan cobaan. Setiap individu tidak terlepas dari nikmat dan cobaan dalam menjalankan aktivitas di dunia. Begitu pula interpretasi syukur dalam perbuatan menuntut individu untuk bersabar. Lawan dari sifat sabar jaza' atau berkeluh kesah merupakan perbuatan tercela yang membawa dampak kehancuran terhadap individu tidak ada pilihan lain bagi individu muslim dalam menghadapi segala cobaan kecuali dengan sabar. Oleh sebabnya sabar tidak dapat dipisahkan dengan taslim (berserah diri) dan ridho kepada takdir (qadha) yang telah di tetapkan Allah (Mu'aziroh 2018).

Dalam hal ini peneliti mengkaitkan Terapi Realitas dan Konsep Sabar dalam Physical Distancing terhadap seorang mahasiswi di Asrama Astri Aulia Yogyakarta. Dalam menerapkan sikap sabar bagi mahasiswa tidak mudah terlebih apalagi bagi mahasiswa perantau yang notabennya banyak menghabiskan aktivitas di luar rumah, seperti mengikuti perkuliahan, diskusi, organisasi dan kegiatan sosial lainnya, dalam menerapkan physical distancing tentunya tidak muda bagi mereka untuk menyesuaikan diri dalam kondisi saat ini, hal ini lah yang cenderung membuat mahasiswa bingung, cenderung bosan sehingga banyak bermunculan keluh kesah memikirkan kapan situasi ini berahir dan pada akhirya membuat mereka tidak bisa menerima keadaan. 
Konsep sabar dalam islam memiliki keterikatan terhadap psikologis individu dalam menjalankan physical distancing, dalam hal ini peneliti menghadapi mahasiswa untuk menumbuhkan rasa sabar individu dengan menggunakan terapi realitas. Terapi realitas bertujuan untuk membantu klien menjadi individu yang rasional sehingga memiliki mental yang kuat. Penekan terapi realitas dalam penelitian ini berfokus pada individu sehingga memiliki tanggungjawab terhadap pilihan terhadap tindakan yang dilkaukannya. Pendekatan ini, ditekankan pada tindakan guna menyadarkan individu untuk menanggapi berbagai pilihan yang telah diambil dan bertanggung jawab secara penuh terhadap pilihan. Individu diberi kesempatan untuk memberi tanggapan terhadap pilihannya untuk melakukan physical distancing dan kemudian bertanggung jawab terhadap diri sendiri untuk disiplin melaksanakan apa yang telah menjadi pilihannya. Pada dasarnya tujuan terapi realitas untuk membantu individu agar mampu menetapkan prioritas dan tanggung jawab terhadap pilihan dan tindakan serta langkah yang akan dilakukan individu (Solichah 2020). Hal ini kemudian membutuhkan terapi realitas guna untuk menumbuhkan sikap sabar dalam upaya physical distancing untuk tetap di rumah bagi mahasiwa yang tidak melakukan mudik di situasi seperti ini.

\section{B. Metode Penelitian}

Penelitian ini merupakan penelitian lapangan (field research), dengan menggunakan pendekatan kualitatif fenomenologi. Yang mana, data yang diperoleh bersifat ekploratif, karena data yang diambil lebih menekankan pada penggambaran dan pemahaman lebih yang berasal dari partisipan. Pengambilan data pada penelitian ini menggunakan teknik wawancara, observasi dan dokumentasi. Teknik wawancara dilakukan dengan menggunakan teknik semi terstuktur kepada partisipan, sehingga peneliti mampu lebih mengeklpolrasi data dari partisipan. Partisipan pada penelitian ini menggunakan purposive sampling, yang mana ditekankan pada beberapa persyaratan yang diajukan pada partisipan, persyaratan tersebut diantaranya: 1) partisipan merupakan mahasiswi yang tinggal di Asrama Asri Aulia, 2) partisipan merupakan mahasiwi yang tetap tinggal di asrama selama masa pandemi. Berdasarkan persyaratan 
yang diajukan, maka didapatkan 5 orang partisipan terdiri dari 2 orang mahasiswi pasca sarjana dan 3 lainnya mahasiswi S1.

Setelah data diambil dari partisipan, maka data akan di olah dan dianalisis dengan menggunakan analisis holistik. Sebelum data diolah maka data terlebih dahulu dilakukan validasi dengan menggunakan member checking.

\section{Pembahasan}

Dalam upaya pemberian bantuan terhadap klien yang sedang menerapkan physical dispensing dalam aktivitas keseharian tentunya tidak jarang mengakibatkan klien tersebut merasakan cemas dan tidak nyaman terlebih apabila mereka saat ini mau tidak mau harus melakukan hal tersebut kepada orang-orang terdekat seperti sahabat atau teman-teman di sekitarnya.

Dalam menyikapi hal ini tentunya dibutuhkan kesabaran dalam menerima kondisi yang sedang terjadi, namun dalam upaya memiliki sikap kesabaran yang konsisten tentu tidak mudah pastinya membutuhkan terapi dalam mengoptimalkan konsep kesabaran di dalam diri. Salah satu terapi yang dapat digunakan yakni terapi realitas. dalam hal ini pendekatan yang digunakan yaitu terapi realitas dan konsep sabar alasannya agar klien dapat memiliki fikiran yang positif dan berupaya menyikapi segala sesuatu dengan sabar sehingga jiwa individu tenang dan menyelaraskan dengan spiritual. Dengan demikian saya mengharapkan agar klien tersebut mampu memiliki konsep sabar agar bisa menerima realitas yang ada sehingga mereka terhindar dari pikiran negatif yang memicu kepada kegelisahan sehingga membuat jiwa tidak tenang.

\section{Terapi Realitas}

Terapi realitas merepukan suatu bentuk hubungan pertolongan yang praktis, relative sederhana dan bentuk bantuan langsung kepada individu yang dilakukan oleh konselor dalam rangka mengembangkan dan membina kesehatan mental konseli yang bersangkutan (Corey 1997). Terapi realitas dipelopori oleh seorang tokoh yang dikenal dengan William Glasser pada tahun 1950-an. Terapi realitas merupakan suatu pendekatan yang dikembangkan sebagai bentuk reaksi melawan 
terapi konvensional, dan berfokus pada kondisi saat ini, menekankan pada kekuatan pribadi serta mendorong individu untuk mengembangkan tingkah laku yang lebih realistik. Istilah terapi realitas ini pertama kali dipergunakan oleh Glasser ketika mengajukan makalah dengan judul Reality Therap, A Realistic Approach to the Young Offender pada suatu pertemuan mengenai kriminologi. Dan satu tahun kemudian terbitlah buku dasar terapi realitas (Gunarsa 2007).

Terapi realitas bentuk modifikasi perilaku menggunakan tekni dengan tipe pengondisian operan yang tidak ketat sehingga mudah dipraktikkan oleh para konselor baik dalam menangani individu maupun kelompok dan biasanya banyak diterapkan di psikoterapi, konseling, pengajaran, konseling perkawinan, pengelolaan lembaga dan pengembangan masyarakat (Lubis 2011).

a. Dinamika Kepribadian Manusia

Dalam hal ini manusia bebas menentukan pilihan dalam artian bebas memilih tingkah lakunya sendiri dan bertanggung jawab terhadap pilihannya serta menerima konsekuensi dari tingkah lakunya. Bertanggung jawab di sini bukan hanya terhadap pilihan namun juga terhadap apa yang dipikirkannya (Lubis 2011). Dalam diri inidividu ada suatu kebutuhan psikologis tunggal yang hadir sepanjang hidup yakni kebutuhan akan identitas yakni kebutuhan untuk merasakan keunikan, keterpisahan dan ketersendirian. Pembentukan identitas: mengembangkan keterlibatan-keterlibatan dengan orang lain dan dengan bayangan diri, yang dengannya kita merasa relative berhasil atau tidak berhasil. Terapi realitas membantu klien dalam memenuhi kebutuhan-kebutuhan dasar psikologisnya yang mencakup 'kebutuhan untuk mencintai dan dicintai serta kebutuhan untuk merasakan bahwa kita berguna baik bagi diri sendiri maupun bagi orang lain. Penderitaan pribadi bisa diubah hanya dengan perubahan identitas, karena individu-individu bisa mengubah cara hidup, perasaan, dan tingkah lakunya, maka merekapun bisa merubah identitasnya.

b. Konsep Terapi Realitas 
Dalam terapi realitas Glasser mengkonsepkannya ke dalam delapan langkah. Pertama, berteman atau mendampingi, melibatkan diri, kemudian menciptakan dan membangun hubungan serta relasi yang baik antar keduanya. Konsep kedua, titik fokus adalah apa yang sedang dikerjakan klien tanpa harus melibatkan sejarah kehidupannya di masa lalu. Ketiga, membantu klien untuk mengevaluasi mengenai tingkah lakunya, Keempat, dalam hal ini setelah proses evalusai selesai, konselor mengekslorasi perilaku alternative yang berguna bagi klien, konsep kelima, disebutkan oleh Glasser konselor memiliki komitmen kepada rencana perubahan sebagai tahap yang dianggap penting. Keenam klien juga melakukan hal yang sama untuk melakukan komitmen sebuah perubahan dan belajar bertanggung jawab dalam menuntaskannya. Konsep ketujuh, tegas tanpa menghukum atau terhukum, kedelapan, menyadarkan klien bahwa konselor menolak untuk menyerah dalam menuntaskan terapi realitas sehingga klien merasa didukung sehingga klien juga akan mengupayakan perubahan yang lebih efisien (Gibson and Mitchell 2008).

Sebagaimana dinamika manusia dan konsep terapi, Glasser kemudian mengidentifikasi perilaku secara keseluruhan yaitu perilaku aktif, pikiran, perasaan dan fisiologi, hal ini sebagai kapasitas yang bertujuan menghasilkan mekanisme tubuh yang dikehendaki atau tidak.Glasser juga meyakini teori control bisa membantu individu menjadi lebih efektif atas hidup klien sehingga kebutuhannya terhadap pilihan yang diambil dapat terpenuhi (Gibson and Mitchell 2008).

\section{c. Tujuan dan Fungsi Terapi Realitas}

Tujuan terapi realitas secara umum agar klien menemukan jalan yang lebih efektif untuk memenuhi kebutuhan-kebutuhannya (Gunarsa 1996). Konselor menyediakan kondisi yang mampu membantu klien dalam mengembangkan kekuatan psikologis untuk mengevaluasi perilaku dan terapis 
mendorong klien untuk membuat assesmen tentang gaya hidup yang sekarang sehinggan klien dapat mengukur perilaku yang telah mereka pilih. Klien diajarkan mengenai fungsi dari kebutuhan dasarnya dan meminta untuk mengenali keinginannya lebih spesifik, tujuan dan arah.

Tugas dasar terapis melibatkan diri dengan klien dan kemudian membantunya menghadapi kenyataan yang sedang dihadapi. Terapis bertindak sebagai pembimbing yang membantu klien agar bisa menilai tingkah lakunya sendiri secara realistis. Dan terapis memberikan pujian apabila klien bertindak dengan cara yang bertanggung jawab dan menunjukkan ketidaksetujuan apabila klien tidak menunjukkan demikian. Karena terapis berperan sebagai seorang guru, mengajari klien bahwa tujuan terapi tidak diarahkan kepada kebahagiaan tetapi klien harus mampu menciptakan kebahagiaannya sendiri yang kuncinya terletak pada penerimaan tanggung jawab. Fungsi terapis dalam praktik terapi memasang batas-batas, mencakup batas-batas dalam situasi terapeutik dan batasbatas yang ditempatkan oleh kehidupan seseorang

d. Ciri-ciri Terapi Realitas

Ciri-ciri terapi realitas diantaranta: (1) terapi realitas menolak konsep tentang penyakit mental. Terapi ini mempersamakan gangguan mental dengan tingkah laku yang tidak bertanggung jawab, dan mempersamakan kesehatan mental dengan tingkah laku yang bertanggung jawab. (2) Berfokus pada tingkah laku yang sekarang dan menekankan kesadarana atas tingkah laku sekarang. (3) Berfokus pada saat sekarang, bukan masa lampau. Masa lampau tidak bisa diubah, yang bisa diubah hanyalah masa sekarang dan yang akan datang. Terapis mencari kekuatan-kekuatan klien dan menegaskannya dalam percakapanpercakapan. (4) Menekankan pertimbangan-pertimbangan nilai. Peran klien dalam menilai kualitas tingkah lakunya sendiri dalam menentukan apa yang membantu kegagalan yang dialaminya. (5) Tidak menekankan transferensi. Terapis menempuh cara beradanya yang sejati yakni bahwa mereka menjadi diri sendiri, tidak memainkan peran sebagai ayah atau ibu. (6) Menekankan aspek- 
aspek kesadaran, bukan aspek-aspek ketaksadaran. (7) Menghapus hukuman karena dianggap tidak efektif. (8) Menekankan tanggung jawab sebagai kemampuan untuk memenuhi kebutuhan-kebutuhan sendiri dan melakukannya dengan cara yang tidak mengurangi kemampuan orang lain dalam memenuhi kebutuhan-kebutuhan individu.

e. Tahap-tahap Teraoi Realitas

Prosedur terapi realitas memiliki empat langkah yang dikenal dengan WDEP yaitu Wants, Direction and doing, Evaluation, and then Planning and commitment. Wants sebagai tahapan eksplorasi terhadap harapan klien, kebutuhan dan persepsi individu saat ini. Tahapan terapi realitas dilakukan dengan wawancara sebagaimana terapi-terapi pada umumnya, sehingga mendorong klien mengenali, menggambarkan dan menyaring bagaimana kebutuhan klien ditemukan. Album gambar dalam pikiran atau quality world (persepsi tentang kualitas hidup). Eksplorasi akan wants, needs and perceptions yang dilakukan dalam proses konseling untuk mengubah gambaran (pictures change) klien. Pada esensinya konselor mampu mendorong klien untuk melakukan proges yang lebih baik. Direction and doing, terapis atau konselor mendiskusikan mengenai perilakau yang ditunjukkan oleh klien saat ini. Evaluation terapis atau konselor mengajak klien untuk mengevaluasi perilakunya, apakah perilaku yang ditampilkan klien sudah cukup rasional untuk mewujudkan harapan, ketika klien sudah cukup rasional maka konselor masuk pada tahap akhir, namun jika klien belum bisa cukup rasional terhadap tingkah laku dan pola pikirnya dengan realitas yang sedang terjadi sekarang maka konselor tidak dapat melakukan tahap selanjutnya melainkan mendiskusikan kembali sampai klien benar-benar menunjukkan atau menampilkan perilaku yang rasional. Tahap terakhirnya adalah planning and commitment, tahap ini konselor mengajak individu sebagai klien untuk mengeksplorasikan bentukbentuk perilaku yang dapat mewujudkan harapannya dan membuat rencana aksi yang berkelanjutan (Siregar 2013). 


\section{f. Peran Konseling}

Glasser merumuskan peran konselor dalam 3R yaitu Right, Responbility and Reality. Right atau kebenaran merupakan tolak ukur atas pedoman seseorang dalam menerima tingkah laku, sikap, perilaku dari lingkungan sekitar. Dalam hal ini individu dapat melakukan evaluasi diri ketika telah melakukan hal yang telah dikerjakan dengan membandingkan kondisi nyaman atau tidaknya, setelah melakukan apa yang dirasa mampu membuat nyaman kemudian individu mampu bertingkah laku sesuai tuntutan lingkungan. Responbility tanggung jawab individu dalam memenuhi kebutuhan diri tanpa harus melibatkan orang lain karena klien akan bertanggung jawab terhadap pilihannya. Sedangkan Reality sebagai suatu hal yang akan menjadi suatu tantangan dalam hidup individu dalam proses memahami dan menerjang alur kehidupan yang nyata sehingga mampu bersaing dengan hukum alam.

\section{Konsep Sabar}

Para ulama membagikan sabar ke dalam tiga kategori diantaranya sabar dalam ketaatan kepada Allah, sabar untuk meninggalkan kemaksiatan, dan sabar menghadapi ujian dari Allah (Hawwa 2005). Pertama, sabar dalam ketaatan kepada Allah, yakni merealisasikan segala bentuk perintah yang telah ditetapkan oleh Allah dalam kehidupan umat manusia meliputi salat tepat waktu, puasa di bulan ramadhan, puasa sunah, membayar zakat, bersedekah, naik haji. Ditinjau dari penyebabnya terdapat tiga hal yang menyebabkan individu sulit untuk sabar yaitu, malas, bakhil atau kikir dan karena keduanya. Kedua sabar dalam meninggalkan kemaksiatan seperti menjauhi larangan berzina, berbohong, ghibah, dusta dan lain sebagainya. meninggalkan maksiat seperti hal yang telah disebutkan seyogyanya juga membutuhkan kesabaran yang besar. Ketiga, sabar dalam menghadapi ujian dan cobaan dari Allah. seperti pandemic yang sedang berlangsung sekarang yaitu corona virus. Dalam hal ini individu dituntut sabar untuk tidak keluar dan tetap di rumah, melakukan segala aktivitanya, tidak melakukan interaksi dan pertemuan melalui tatap muka langsung. Sabar ketiga ini bisa berupa kehendak sendiri maupun 
anjuran atau protocol dari pemerintah. Apabila sabar karena kehendak sendiri, ini merupakan salah satu bentuk empati yang sangat baik yang memberikan dampak positif dalam hidup. Dan ketika kesabaran sebagai keharusan akan berakibat boomerang bagi diri sendiri karena sabar tersebut tidak sesuai dengan kehendak hati.

Situasi yang mengharuskan seseorang untuk bersabar meliputi karena perintah Allah, dimensi ini berfokus pada hal-hal yang membuat individu untuk menjalankan segala perintah Allah dengan baik dan konsisten seperti semangat dalam menuntut ilmu. Situasi berikutknya karena larangan dari Allah. untuk melakukan hal-hal yang tidak baik atau tidak tidak disukai oleh Allah, selanjutnya situasi karena musibah. Dengan menerima segala bentuk ketidak baikan yang sedang menimpa diri, bukan berarti menyalahkan Allah sebagai sang pemberi kejadian, tetapi berupaya menerima cobaan dengan penuh kesabaran karena akan ada hikmah dibalik semua peristiwa yang terjadi. Dan terakhir situasi dalam hal nikmat Allah, ini merupakan dimensi yang paling rinngan untuk dipraktekkan, orang yang mampu bersabar dalam menerima nikmat Allah adalah mereka yang pandai bersyukur (Ramdani and Supriyatin 2018). Pada masa sekarang ini sabar mematuhi protocol pemerintah harus direalisasikan walaupun hal tersebut bertentangan dengan kehendak individu karena hal ini dilakukan pemerintah juga demi masyarakatnya agar bisa tetap bertahan hidup.

Kesabaran bukan hanya semata-mata memiliki pengertian menerima begitu saja. Sabar sesungguhnya memiliki dimensi untuk mengalahkan hawa nafsu yang terdapat dalam jiwa manusia. Sabar juga memiliki sisi yang mampu mengubah sebuah kondisi, baik yang bersifat pribadi maupun sosial, menuju perbaikan ke arah yang lebih baik sebelumnya. Dan hal yang mampu menjadikan individu untuk bersabar adalah dengan memahami tentang kedudukan sabar. Ketika seorang individu berupaya memahami ruang lingkup kesabaran maka ia akan mengerti bahwa alam juga tegak di atas kesabaran. Apabila diamati dengan teliti kita akan mengetahui bahwa alam tegas di atas peinsip kesabaran yakni kebertahapan. 
Matahari tidak mengejutkan manusia dengan muncul secara tiba-tiba di langit luas, matahari terbit dan naik secera berlahan sehingga memberikan sinar terang begitupun ketika tenggelam, secara perlahan sinar akan tenggelam dan hilang. Begitupun dengan manusia, terciptakan dari proses paling rumit dan Panjang (Raihanah 2016). Sama juga halnya corona virus, yang lahir ke dunia dengan proses yang rumit dan panjang, bahkan orang islam melabelnya sebagai takdir atau rekayasa tangan tuhan

Sabar merupakan sebuah kekuatan, daya positif yang mendorong jiwa untuk menunaikan suatu kewajiban. Dan sabar juga suatu kekuatan yang menghalangi seseorang untuk melakukan kejahatan atau bahkan sesuatu yang dapat merugikan diri sendiri. Hakikat sabar adalah satu akhlak mulia yang mampu menghalangi timbulnya aktifitas yang tidak baik dan tidak memikat. Sabar adalah satu energi jiwa dengan berbagai urusan jiwa menjadikan lebih baik dan tuntas. Dari uraian tersebut kita dapat menilai bahwa orang yang memiliki sifat sabar, mereka mampu dan siap menghadapi ketidaknyamanan bahkan tidak berkeluh kesah ataupun berputus asa. Dalam hal ini bukan berarti sabar tidak boleh mengeluh, mengeluh menandakan sifat kemanusiawinan seorang individu, tetapi mengeluh pada tempat yang benar dan sesuai kadar atau kapasitasnya. Mengeluh kepada Allah sebagaimana yang telah dicontohkan oleh orang-orang terdahulu, nabi Ayub a.s. misalnya "Hanya kepada Allah aku mengadukan kesusahan dan kesedihanku” (Qs. Yusuf:86)

Sabar tersusun dari pengetahuan (ilmu), kondisi (hal) dan praktik (amal). Pengetahuan diibaratkan sebagai pohon, kondisi sebagai dahan, dan amal sebagai buahnya. Kita ketahui bahwa kemaslahatan agama terletak pada kesabaran hingga akhirnya kesabaran itu memunculkan kekuatan yang saling memotivasi untuk berlaku sabar. Kesabaran bisa dalam hal ibadah atau pelampiasan syahwat. Semua ini dalam semua kondisi, didorong untuk menuju pada perilaku sabar sehingga dalam hal-hal yang mudah, dengan kesabaran seseorang tidak akan melampaui batas kewajaran dengan melakukan hal-hal yang berlebihan (Bakhri 2016). 
Menurut analisis Indarawati Kamila dan Ujang Endang dalam artikelnya berjudul relevansi pendidikan islam dengan konsep sabar menurut imam AlGhazali dalam kitab Ihya Ulumuddi, bahwa sabar dalam persektif islam sebagai akhlak mulia orang-orang beriman yang mampu menghalangi munculnya tindakan tidak baik atau tidak patuh, dalam perspektif imam Ghazali adalah konsep utama yang wajib dilalui dan dijalani orang beriman (Indarawati and Endang 2016).

Al-Ghazali mendefinisikan sabar sebagai suatu proses untuk meninggalkan perbuatan-perbuatan yang penuh dengan nafsu syahwat yang dihasilkan oleh suatu keadaan (Indarawati and Endang 2016). Sabar menjadi model perilaku dalam menghadapi berbagai macam musibah yang melanda Indonesia bahkan dunia seperti bencana, kriminalitas, bahkan musibah yang menjadikan manusia krisis kesehatan yaitu covid-19. Bagi orang yang sabar akan menerima semua dengan lapang dada yang dibuktikan dengan menaati dan memperindah himbauan pemerintah untuk tetap di rumah (stay at home), namun bagi individu yang tidak memiliki sifat bersabar dibuktikan dengan sifat keputus asaanya atau tidak mengindahkan protocol yang disampaikan oleh para ahli medis saat ini. Indicator sabar menurut Al-Ghazali yaitu mampu menahan diri dari putus asa, berserah diri kepada Allah, tidak mengeluh dengan situasi dan kondisi yang sedang dihadapi, tenang, segala sesuatu yang terjadi memiliki hikmah yang luar biasa dari sang pencipta.

Orang sabar atau rational thinking, mengacu pada keadaan pikiran yang selalu positif saat ditimpa masalah, menimbulkan pikiran yang jernih dan selalu melihat keadaan secara menyeluruh dan berhati-hati dalam bertindak. Self Acceptance kemudian menerima dengan sepenuh hati segala sesuatu yang telah terjadi menimpa diri baik yang bersifat menguntungkan maupun hal negative, lalu akan muncul perilaku untuk selalu memanfaatkan apa yang ada, dan suka dalam melakukan feedback terhadap diri sendiri. Selanjutnya timbul self control suatu keadaan yang menentukan keseimbangan emosional dalam diri. Aspek ini berfokus pada keadaan untuk menahan sesuatu secara seimbang, memunculkan perasaan 
tenang dalam diri, mampu mengendalikan segala sesuatu secara psikis, dan biasanya sangat principal kepribadiannya. Dan effort, mengacu pada kerja keras atau usaha yang lebih, tanpa putus asa ketika dihadapkan pada permasalahan yang begitu banyak dan konpleks sehingga mampu bangkit dan mencari jalan keluar (Ramdani and Supriyatin 2018). Kelima point ini bentuk penerimaan diri dalam hal sabar menerima ujian dari yang Maha Kuasa.

\section{Diskusi}

Social distancing merupakan upaya yang dilakukan oleh pemerintah guna memutus mata rantai penyebaran covid 19. Yang mana, di dalamnya di terapkan physical distancing. Kondisi semacam itu, menjadikan perubahan dalam kehidupan individu. Salah satunya yakni kondisi psikologis individu, yang mana akan menjadi pemicu terjadinya kecemasan ataupun ketidaknyamanan dalam diri individu (Galea, Merchant, and Lurie 2020). Bentuk kebosanan ataupun kecemasan yang terjadi pada diri individu biasanya disebut sebagai cabin fever (Admin 2020). Kondisi semacam itu, tentu saja perlu adanya pemyikapan tersendiri, salah satunya dapat dilakukan dengan melakukan terapi.

Terapi tersebut akan menjadikan dukungan tersendiri pada diri individu guna menghadapi perubahan kondisi psikologis dan juga menumbuhkan kesabaran dalam dirinya (Mubasyaroh 2019). Salah satu terapi yang digunakan dalam memnghadapi perubahan kondisi psikologis pada masa pandemic covid 19 yakni terapi realitas. Terapi realitas ini menekankan pada pola pikir individu yang lebih positif, sehingga mampu memunculkan sikap sabar dalam dirinya. Yang mana, mampu menekan berbagai kegelisaan ataupun kecemasan sehingga meminimalisir berbagai bentuk pola pikir negative.

a) Bentuk Pemahaman Physical Distancing Melalui Terapi Realitas

Terapi realitas merupakan suatu bentuk hubungan pertolongan yang praktis, relative sederhana dan bentuk bantuan langsung kepada individu yang dilakukan oleh konselor dalam rangka mengembangkan dan membina kesehatan 
mental konseli yang bersangkutan (Corey 1997). Pada terapi ini ditekankan pada kekuatan yang ada dalam diri setiap individu yang mampu mengembangkan perilaku yang lebih realistic (Gunarsa 2007). Yang mana, difokuskan pada setiap individu dapat bebas memilih dan bertanggung jawab atas pilihan perilaku nya sendiri (Lubis 2011).

Pengaplikasian terapi realitas difungsikan agar setiap individu mampu mengambil sikap, arah dan tujuan secara tanggung jawab dalam menentukan perilaku yang sesuai dengan bentuk perilaku yang telah di pilih oleh setiap individu untuk memenuhi kebutuhannya masing-masing (Gunarsa 1996). Sehingga pada pengaplikasian social distancing yang dilakukan dalam menekan pertumbuhan penyebaran covid 19, dapat di aplikasikan.

Bentuk pengaplikasian terapi realitas dalam pelaksanaan social distancing yang dilakukan yakni dengan memberikan arahan kepada partisipan agar mampu memahami kondisi dan mengaplikasikannya secara konkret. Salah satunya dengan Hal tersebut sesuai dengan fungsi dari terapi realitas yang disampaikan oleh Gunarsa (1996) bahwa dengan dilakukannya terapi realitas kepada individu bertujuan agar setiap individu mampu bertanggung jawab serta mengambil tindakan sesuai dengan keyakinan masing-masing. Terkait dengan kegiatan social distancing yang dilakukan dalam penelitian, maka terapi realitas mampu memberikan pandangan kepada partisipan guna mengembangkan perilaku yang sesuai dengan ketetapan social distancing baik yang ditetepkan WHO ataupun pemerintah, yang bukan hanya dalam bentuk kepatuhan semu akan tetapi dalam bentuk keasadaran serta tanggung jawab pribadi.

Pelaksanaan terapi relitas yang dilakukan kepada konseli/ partisipan guna membentuk pemahaman tentang social distancing, maka seorang konselor berperan; 1) Righ; Right dipandang sebagai bagian dari tolok ukur dalam diri individu untuk melakukan tindakan. Peran ini dilakukan oleh konselor guna mengembangkan sikap dalam diri individu yang di lakukan oleh partisipan/ konseli sehingga mampu menerima ataupun menolak lingkungannya (Siregar 
2013). Dalam penelitian ini ditemukan hasil bahwa, partisipan menerima social distancing yang di dalamnya mencakup physical distancing. Yang mana, perilaku yang ditampakkan partisipan ditekankan denga cara mampu terlihat dalam kegiatan sehari-hari yang dilakukan dengan cara menjaga jarak social jika keluar dari asrama dan/ atau tidak melakukan kegiatan di luar ruangan/ asrama jika tidak ada kepentingan yang memang mendesak dan tidak bisa di tinggalkan.

Guna mendapatkan peran Right yang maksimal yang dilakukan oleh konselor dan memberikan pemahaman sehingga partisipan mampu menerima dan menyesuaikan diri dengan lingkungan yang sekarang di hadapi (Siregar 2013). Seorang konseli harus melalui proses tahapan dari terapi realitas pada tahapan wants (Willis 2004). Wants yang dilakukan dalam kegiatan konseling realitas yang dipraktikkan dalam penelitian ini, dengan cara dilakukan wawancara kepada partisipan/ konseli terkait dengan hal-hal yang di pahami partisipan, yang di rasakan selama kegiatan social distancing dan juga perasaan yang dirasakan selama social distancing. Yang mana, sehingga mampu mengetahui berbagai aspirasi dan yang dirasakan oleh setiap partisipan.

Berdasarkan hasil penelitian di dapatkan bahwa, partisipan dalam memahami social distancing sebagai bagian dari peraturan pemerintah guna menekan tertularnya virus covid 19 . Hal tersebut di dukung oleh hasil penelitian yang diungkapkan oleh Mona (2020) bahwa penyebaran covid 19 terjadi secara contagious. Ini berarti bentuk penyebaran secara cepat dalam jaringan tubuh sama halnya dengan flu, maka alangkah baiknya dilakukan social distancing maupun psychical distancing dalam pencegahan dan pemutusan mata rantai pencegahan covid 19.

b) Pembentukan dan Pengembangan Kesabaran diri dalam Pelaksanaan Psychical Distancing

Corona virus 2019 atau yang sering disebut dengan covid 19 merupakan wabah yang sedang melanda sebagian wilayah yang ada di dunia (Mona 2020). 
Dalam konteksnya pihak medis dan juga pemerintah menghimbau berbagai upaya preventif guna peningkatan ketahanan tidak hanya fisik, melainkan juga mentalitas setiap individu. Peningkatan ketahanan mentalitas individu dapat dilatih dan ditumbuhkan melalui sabar.

Sabar dapat diartikan sebagai suatu perbuatan yang di dalam nya mencakup berbagai hal yang berkaitan dengan kemampuan seorang individu dalam meminimalisir bahkan memhilangkan kegelisahan dalam dirinya, bersikap tenang saat mengalami suatu musibah, yang berdasarkan atas kepatuhan dan ketaatan kepada Allah (Hadi 2018). Hal tersebut dapat digaris bawahi bahwa perilaku yang di bentuk dari hasil kesabaran berkaitan dengan kepercayaan dan keyakinan kepada Allah SWT.

Letak kepercayaan yang menjadi dasar dari adanya kesabaran dalam diri setiap individu dapat di lihat dari kisah nabi Ibrahim as, yang tercantum dalam QS. Asy-Syu'ara: 80, artinya “Dan apabila aku sakit, Dialah yang menyembuhkan aku". Sehingga hal tersebut dipandang sebagai sesuatu yang telah ditakdirkan sesuai dengan kehendak-Nya. Bentuk kepasrahan atas segala sesuatu yang ditakdirkan sesuai dengan kehendak-Nya, menurut para ulama disebut sebagai sabar (Hawwa 2005).

Dalam lingkup psikologi, konsep sabar menurut Yusuf and Kahfi (2018) berkaitan dengan self control (control diri); resiliensi (ketabahan); perseverance (kegigihan); serta Self Acceptance. Al Jauziah (dalam Subandi 2011) mengungkapkan bahwa konsep sabar di bedakan dalam konteks bentukya dan jenisnya. Berdasarkan bentuknya, konsep sabar dibedakan menjadi sabar jasmani dan rohani. Berdasarkan jenisnya, sabar dibedakan menjadi sabar menerima perintah, menjauhi larangan dan menerima takdir sesuai dengan kehendak-Nya.

Sabar merupakan bagian dari wujud keimanan dan ketaqwaan kepada Allah SWT. Yang mana, dibalik perilaku sabar yang terbentuk dalam diri individu maka akan menjadikan peningkatan kebersyukuran, keberkahan serta kenikmatan 
dari Allah (Muaziroh 2018; Ramdani and Supriyatin 2018). Kesabaran dalam masa pandemic covid 19 seperti sekarang ini, perilaku sabar dilakukan dengan melaksanakan psychical distancing. hal tersebut dilakukan dengan cara tetap menjalankan protocol kesehatan, serta mematuhi peraturan pemerintah yang terkait dengan peraturan jarak social yang telah ditetapkan.

Pada penelitian ini, kesabaran bukan hanya di artikan secara harfiah, yang mana mampu menerima kondisi tanpa adanya pengetahuan yang mendukung. Melainkan bentuk kesabaran yang di barengi dengan ikhtiyar demi menjaga keamanan bersama, baik diri sendiri, keluarga maupun masyarakat sekitar.

c) Relevansi Terapi Realitas dan Konsep Sabar pada psychical distancing

Dalam konteks corona virus para tenaga medis menganjurkan sekian banyak langkah-langkah sebagai upaya preventif penyebaran virus sebagaimana telah penulis singgung sebelumnya. Para intelektual menganjurkan untuk meningkatkan kesiapan dan ketahanan fisik maupun mental. Agamawan pun ikut menganjurkan sekian banyak hal seperti dimensi yang menyangkut dengan kepercayaan kepada Tuhan dan mengukuhkan kebenaran ucapan Nabi Ibrahim a.s. dalam alquran surah asy-Syu'ara ayat 80 "Dan apabila aku sakit, Dialah yang menyembuhkan aku”. Di sinilah letak kepercayaan dan kekuatan doa bagi orang muslim dan dibarengi dengan sifat sabar. Sehingga individu merasakan ketenangan, adanya dorongan kekuatan batin dalam menghadapi musibah atau cobaan berupa covid-19. Untuk itu mari kita sebagai seorang muslim meyakini bahwa yang terjadi atas kehendak Allah (kun fayakun).

Kun fayakun, bukan berarti yang dijadikan-Nya tidak melalui proses. Penggalan ayat quran surah yasin ini bahwa Allah Maha Kuasa dan terbebasnya Dzat Allah dari waktu tanpa bahan atau proses, namun secara umum semua proses atas kehendak-Nya karena Allah lah yang menciptakan dan menyempurnakan ciptaannya, menentukan kadarnya untuk setiap masing-masing ciptaannya. Dianalogikan seperti rumput-rumput, kapan dan bagaimana dia tumbuh 
menghijau, atau bahkan kering dan layu. Dan kadar atau ukuran tersebut sangat berkaitan erat dengan waktu, bentuk, sifat, potensi masing-masing ciptaan-Nya yang memiliki perbedaan antara satu dengan lainnya. Takdir itulah yang kemudian dinamai oleh sementara ilmuan secara keliru sebagai hukum alam, yang padahal semestinya merupakan hukum Allah yang diberlakukan terhadap alam raya Begitupun manusia diberikan takdir sesuai kehendak-Nya tetapi manusia berbeda halnya dengan alam raya atau langit dan bumi. Dunia, alam raya atau langit dan bumi diberikan ketetapan atau takdir oleh Allah tanpa diberi pilihan sehingga bersifat konsisten (Qs. Fushilat : 11). Ketetapan inilah yang kemudian dapat menjadikan manusia dengan pengetahuan dapat menetapkan kapan terbit dan tenggelanya matahari, kapan terjadinya gerhana dan lain sebagainya

Manusia pun kendatinya ditetapkan takdir namun diberikan pilihan dan memiliki kebebasan dalam ruang takdir walaupun manusia sebagai individu biasa tidak mengetahui batas ruang takdir karena dituntut untuk berusaha dan terus berusaha. Ketika manusia telah berusaha semaksimal mungkin tetapi tetap mendapatkan kegagalan, maka ini dinamakan dengan takdir pilihan Allah (Shihab 2020). Sama hal dengan corona virus yang mulanya issu beredar diciptakannya oleh tangan manusia sebagai alat perang untuk memusnahkan manusia dengan tujuan untuk menguasai apa yang ada di atas bumi dan di dalam perut bumi. Para ilmuan dan pakar sedari awal menduga virus corona dihasilkan dari hasil reset pathogen paling mematikan untuk senjata biologi yang mengalami kebocoran di laboratorium penelitian virus di Tiongkok yang dikenal dengan Virologi Wuhan (Rais 2020). Berdasarkan beberapa temuan diantaranya seorang mantan pejabat intelijen militer Badan Intelijen Pusat (CIA) dan mantan spesialis anti-terorisme Amerika Serikat (AS) mengatakan covid-19 tidak muncul secara alami melalui mutasi melainkan diproduksi di laboratorium. Dicurigai Amerika dan Israel terlibat dalam proyek produksi virus sebagai agen perang biologis. Mantan pejabat CIA yang memiliki kecurigaan itu adalah Philip Giraldi. Ia menuliskan 
argumennya dalam sebuah artikel yang diterbitkan oleh Strategic Culture Foundation pada hari kamis (5/3/2020)

Ditilik lebih jauh lagi, pernah dilansir di indopolitika.com (27/1/2020) virus ini mewabah, pengamat menduga ada kaitannya dengan perang dagang Tiongkok-Amerika yang masih berlangsung. Dugaan tersebut pertama kali disampaikan analisis terorisme dan Intelijen Stanislaus Riyanta. Namun hal ini hanya sebuah asumsi yang belum memiliki bukti kuat sehingga perlu kiranya di usut dan diteliti lebih dalam supaya tidak hanya sebatas analisa kasar tanpa didasari bukti yang akurat. Apa pun yang terjadi sekarang, sah saja jika ada yang mengatakan bahwa semua merupakan rekayasa. Dalam islam Allah juga Maha Pembuat rekayasa yang tidak mungkin akan ada makhluk yang mampu mengalahkannya. Umat islam harus meyakini bahwasanya Allah swt., juga memiliki kehendak-Nya sendiri atas apa yang (mungkin) telah direkayasa oleh manusia dan sungguh Allah Maha Berkehendak. Hal ini disampaikan dalam diskusi berteman Covid-19 antara rekayasa dan takdir. Segala sesuatu yang terjadi harus kita yakini bersama bahwa yang terjadi di atas alam (yang baik dan buruk, yang direncanakan atau tidak) semua merupakan takdir dan ketentuan Allah dan kebaikan dan keburukan yang terjadi pada hakikatnya adalah kebaikan bagi orang mukmin.

Hanif Mahaldi mengambil hikmah ditengah pendemik menuliskan buku “Belajar Jualan di Tengah Corona” karena kita ketahui bahwa dengan lahirnya covid-19 semua dipaksa online, dan sosial media merupakan ekpresi atau aktifitas yang bisa dilakukan oleh siapa saja, kapan saja dan di mana saja. Dengan bermodalkan kuota atau wifi sebagai syarat agar bisa mengakses informasi dan berinterasi di tengah pandemic (Mahaldi n.d.).

Walaupun pemerintah dan tenaga medis sebagai garda terdepan dalam menghadapi dan menangani individu yang positif menderita virus corona, tidak hentinya selalu menghimbau masyarakt untuk melakukan physical distancing untuk tetap di rumah saja guna menjaga jarak dengan individu lainnya, namun 
tidak jarang masih saja ada masyarakat yang melanggar himbauan tersebut dengan berbagai macam alasan, seperti bosan melakukan aktifitas di rumah, tidak sabar dan bahkan ada di antaranya yang mengatakan tidak takut pada corona virus dengan dalih takdir ditangan Tuhan. Ini sungguh pembodohan yang nyata, ustadz Das'ad Latif melalui ceramahnya menegaskan, jika manusia tidak takut pada corona sehingga tetap tidak menaati himbauan pemerintah dan akhirnya meninggal karena corona, maka mati konyol namanya. Dengan hal ini adanya bantuan konseling terapi realis dan konsep sabar mampu memantapkan keyakinan seorang individu dalam mendisiplinkan physical distancing salah seorang mahasiswa yang tidak bisa mudik karena terjebak dalam pandemic di perantauan.

Pada dasarnya Allah bebas berhendak terhadap seorang hamba apakah akan terkena penyakit corona virus atau tidak. Namun mestinya manusia paham dan mengerti bagaimana proses kehendak Allah terjadi. Pakar agama mengatakan bahwa kehendak Allah terdiri dari dua dimensi, pertama, dinamai dengan iradah kawniyah yaitu ketentuan yang tidak mengalami perubahan sehingga pasti akan terjadi. Dan dimensi yang kedua iradah syar'iyah, dimensi ini berkaitan dengan hal yang direstui oleh Allah, artinya sesuatu yang belum pasti terjadi karena dalam dimensi kedua atau kehendak syar'iyah terdapat campur tangan manusia yaitu adanya usaha manusia. Allah senang apabila hamba-Nya patuh, tetapi Allah tidak akan memaksa mereka. Oleh karenanya siapa yang patuh dan enggan tergantung pilihan manusia itu sendiri dan setiap pilihan pastinya ada konsekuensi tertentu yang harus diterima (Shihab 2020). Begitu pun berlaku bagi situasi pandemic yang sekarang sedang terjadi, ketika hadirnya usaha dari seorang individu untuk menaati himbauan pemerintah melakukan physical distancing seperti stay at home untuk tetap di rumah, menjaga jarak, meningkatkan pola hidup bersih, menggunakan masker dan lainnya. Maka adanya usaha dan campur tangan manusia kehendak Allah agar tidak menjadi pasien positif corona kemungkinan akan dikehendaki oleh Allah. Inilah yang dinamakan dengan iradah syar'iyah. Dengan memilih untuk mematuhi aturan yang diberlakuakan maka individu akan 
mendapatkan konsekuensi dari usahanya yaitu terhindar dari corona virus. Ketika upaya yang dilakukan seseorang dalam bentuk ikhtiar untuk tetap di rumah saja dalam situasi pandemic sekarang, dalam usaha akan ada titik temu di dalamnya yaitu sabar. Proses sabar yang mesti dicapai oleh individu sehingga kehendak Allah datang kepadanya sampai pandemic ini berlalu.

\section{Simpulan}

Pelaksanaan kegiatan konseling dengan menggunakan pendekatan terapi realitas dan konsep sabar terhadap klien cukup baik dalam memberikan dampak perubahan perilaku yang dialami klien. Sebelumnya klien memang selalu bingung, resah, bosan dan sering berkeluh kesah karena klien belum bisa membiasakan dirinya untuk menerapkan physical distancing terlebih karena klien sering aktif di luar asrama untuk mengikuti kegiatan. Rutinitas yang biasa dilakukan harus tertunda beberapa waktu disebabkan oleh wabah covid-19, dengan melihat realitas yang ada tentunya membuat klien mau tidak mau mematuhi peraturan yang berlaku maka sebab itulah dengan diberikannya pendekatan terapi realitas yang diintegrasikan dengan konsep kesabaran salah satu cara yang cukup efektif untuk mengurangi permasalahan klien. Meskipun setelah konselor berupaya memberikan konseling dengan pendekatan realitas dan konsep sabar tidak sepenuhnya mampu menghilangkan kegundahan klien yang rasakan secara total namun setidaknya klien mampu menurunkan tingkat kegelisahan yang dirasakan dan jauh lebih stabil daripada perilaku sebelumnya dan klien merasa jauh lebih tenang ketika berpasrah diri kepada Allah dengan kondisi yang terjadi saat ini.

Dilihat dari sisi agama, terapi realitas mampu mengawetkan rasa sabar dalam kehidupan individu. Peneliti memberikan saran kepada para pembaca agar menjadikan sabar sebagai senjata paling ampuh dalam menghadapi berbagai macam masalah di dunia terutama covid-19 yang sedang menjamur di Indonesia. Bagi akademis yang berkecimpung dalam pendidikan psikologi, konseling dan sejenisnya, diharapkan bisa memanfaatkan terapi realisan dan konsep sabar untuk 
menangani orang-orang terdekat yang mengalami berbagai gejolak emosional dalam melakukan physical distancing. Dan di harapkan juga bagi para remaja, orang tua dan dewasa memiliki kesabaran dalam menghadapi covid-19 dengan melalukan physical distancing serta melaksanakan himbauan pemerintah serta protocol yang telah disampaikan oleh tenaga medis. 


\section{DAFTAR PUSTAKA}

Admin. 2020. "Mengenal Cabin Fever Dan Cara Mengatasinya." Universitas Indonesia.

Anon. 2020. "No." Kids Grid.

Bakhri, Ahmad Abdurraziq Al. 2016. Ringkasan Ihya' Ulumuddin. Bekasi: PT Sahara.

Bruno, Del Medico. 2020. Corona Virus-19: Membela Diri, Cara Menghindari Penularan, Bagaimana Melindungi Keluarga Dan Pekerjaan Anda (Manual Pertama Untuk Mempertahankan Diri Terhadap Infeksi Corona Virus). Portugis: PT Portugues.

Corey, Gerald. 1997. Konseling Dan Psikoterapi : Teori Dan Praktik. Bandung: PT Eresco.

Galea, Sandro, Raina M. Merchant, and Nocole Lurie. 2020. The Mental Health Consequences of Covid 19 and Physical Distancing. Amerika.

Gibson, Robert L., and Marianne H. Mitchell. 2008. Bimbingan Dan Konseling. 7th ed. Yogyakarta: Pustaka Pelajar.

Gunarsa, Singgih D. 1996. Konseling Dan Psikoterapi. Jakarta: BPK Gunung Mulia.

Gunarsa, Singgih D. 2007. Konseling Dan Psikoterapi. Jakarta: Gunung Mulia.

Hadi, Samsul. 2019. Mers, Corona Virus. Yogyakarta: Cordovia Publisher.

Hadi, Sopyan. 2018. “Konsep Sabar Dalam Al-Qur'an.” Madani 1(2):473-88.

Hawwa, Said. 2005. Tazkiyaun Nafs, Inisari Ihya Ulumuddin. Jakarta: Pena Pundi Aksara.

Ibadurrahman, Muhammad Alief. 2020. Virus: Asal Usul, Dampak Dan Pencegahan Efektif Covid-19.

Imam, Nurul. 2012. "Studi Komparasi Konsep Sabar Menurut TM. Habsi Ash Shiddiqie Dan Yunan Nasution Dan Relevansinya Dengan Kesehatan Mental (Analisis Bimbingan Dan Konseling Islam)." Institut Agama Islam Negeri (UIN) Walisongo Semarang.

Indarawati, and Ujang Endang. 2016. "Relevansi Pendidikan Islam Dengan Konsep Sabar Menurut Imam Al-Ghazali Dalam Kitab Ihya' Ulumuddin." Jurnal Tarbiyah Al-Aulad 1(2).

Indriya. 2020. "Konsep Tafakkur Dalam Alqur'an Dalam Menyikapi Corona Virus Covid 19." Salam: Jurnal Sosial Dan Budaya Syar'i 7(3):211-16.

Kresna, Arief, and Juni Ahyar. 2020. "Pengaruh Physical Distancing Dan Social Distancing Terhadap Kesehatan Dalam Pandangan Linguistik." Jurnal Sintax Transformation 1(4):14-19. 
Li, Geng, Yaohua Fan, Yanni Lai, Tiantian Han, Zonghui Li, Peiwen Zhou, Pan Pan, Wenbiao Wang, Dingwen $\mathrm{Hu}$, Xiaohong Liu, Qiwei Zhang, and Jianguo Wu. 2020. "Coronavirus Infections and Immune Responses." Journal Of Medical Virology 92:424-32.

Los Angeles Country Departemen Of Public Health. 2020. "Novel Corona Virus 2019 (Covid-2019)." Public Health.

Lubis, Namora Lumongga. 2011. Memahami Dasar-Dasar Konseling Dalam Teori Dan Praktik. 1st ed. Jakarta: Kencana.

Mahaldi, Hanif. n.d. Saatnya Kamu Yang Muda Belajar Berjualan, Belajar Berjualan Di Tengah Corona Karena Semua Di Paksa Untuk Online.

Majelis Ulama Indonesia. 2020. Penyelenggaraan Ibadah Dalam Situasi Terjadi Wabah Covid-19. Indonesia: Majelis Ulama Indonesia.

Mona, Nailul. 2020. "Konsep Isolasi Dalam Jaringan Sosial Untuk Meminimalisasi Efek Contagious (Kasus Penyebaran Virus Corona Di Indonesia)." Jurnal Sosial Humaniora Sosial 2(2):117-25.

Mu'aziroh, Ulfa. 2018. "Aktualisasi Konsep Sabar Dalam Perspektif Al-Qur'an." Jurnal At-Thibyan 3(2):202.

Muaziroh, Ulfa. 2018. “Aktualisasi Konsep Sabar Dalam Perspektif Al-Qur'an (Studi Terhadap Kisah Nabi Ayyub).” Jurnal At-Thibyan 3(2):200-211.

Mubasyaroh. 2019. "Pendekatan Konseling Realitas Dan Terapi Agama Bagi Penderita Psikoproblem." Komunika: Jurnal Dakwah Dan Komunikasi 13(1):81-96.

Presiden RI. 2018. Undang-Undang Republik Indonesia Nomor 6 Tahun 2018 Tentang Kekarantinaan Kesehatan. Indonesia: Peraturan Perundangundangan.

Presiden RI. 2020. Pembatasan Sosial Berskala Besar Dalam Rangka Percepatan Penanganan Corona Virus Disease 2019 (Covid-19). Indonesia: Kementerian Hukum dan Hak Asasi Manusia RI.

Raihanah. 2016. “Konsep Sabar Dalam Al-Qur'an.” Jurnal Tarbiyah 6(1).

Rais, Mukhlis. 2020. Covid 19 Dalam Kacamata Islam, Rekayasa Atau Takdir Allah. Langsa.

Ramdani, Zulmi, and Titin Supriyatin. 2018. "Perumusan Dan Pengujian Instrumen Alat Ukur Kesabaran Sebagai Bentuk Coping Strategi." Jurnal Psikologi Dan Budaya 1(2).

Shihab, M. Quraish. 2020. Corona Ujian Tuhan: Sikap Muslim Menghadapinya. Jakarta: Lentera Hati.

Siregar, Suri Mutia. 2013. "Efektivitas Terapi Realitas Untuk Meningkatkan Self 
Regulated Learning Pada Mahasiswa Underechiver." Analitika 5(2).

Solichah, Novia. 2020. "Konseling Pendekatan Terapi Realitas Untuk Mengatasi Proktinasi Akademik." Jurnal Penelitian Psikologi 11(1).

Subandi. 2011. “Sabar: Sebuah Konsep Psikologi.” Jurnal Psikologi 38(2):215-27.

Sukino. 2018. “Konsep Sabar Dalam Al-Qur'an Dan Kontekstualiasasinya Dalam Tujuan Hidup Manusia Melalui Pendidikan." Ruhama 1(1):63-77.

Supriatna, Eman. 2020. "Wabah Corona Virus Disease Covid 19 Dalam Pandangan Islam.” Salam: Jurnal Sosial Dan Budaya Syar'i 7(6):555-64.

Sya'ban, A. G. 2017. “Dunia Islam.” Republika.Co.Id.

Tasri. 2020. "Hikmah Di Tengah Wabah Virus Corona Dalam Pandangan Islam." Qiyas 5(1):42-50.

Uyun, Quratul, and Rumiani. 2012. "Sabar Dan Sholat Sebagai Model Untul Meningkatkan Resiliensi Di Daerah Bencana Yogyakarta." Jurnal Intervensi Psikologi 4(2).

Willis, Sofyan S. 2004. Konseling Individual: Teori Dan Praktik. Bandung: Alfabeta.

Yusuf, M., and Dona Kahfi. 2018. "Sabar Dalam Perspektif Islam Dan Barat." AlMurabbi 4(2):233-46. 